\title{
Assessment of the innovation ecosystem reproductive potential
}

\author{
Oksana Ivanova* and Svetlana Belikova \\ Don State Technical University, 344000, Rostov-on-Don, Russia
}

\begin{abstract}
The technological development of the national economy in modern conditions is impossible without the creation of a stable innovation ecosystem, capable of a continuous process of the innovations expanded reproduction. Within the framework of the innovation ecosystem, conditions should be created not only for innovation, but also for the active introduction of innovative products. This is especially true for the construction industry, which is the engine of economic growth. In order to analyze the ability of an innovation ecosystem to reproduce innovations, the authors proposed a methodology for assessing the reproductive potential of an innovation ecosystem, which is based on the index method. A distinctive feature of the proposed methodology is the formation of a system of indicators relative to the main stages of innovation reproduction. In most scientific studies, the analysis is based on the assessment of the activities of economic entities involved in innovation. The methodology was tested at the regional level. In this case, an analysis of the industry specifics is possible. The results obtained make it possible to assess the reproductive potential of an innovation ecosystem, to identify the problematic stages in the innovations' creation and implementation, which contributes to the possibility of using the additional levers for intensifying economic growth.
\end{abstract}

\section{Introduction}

Modern realities of social and economic life associated with the impact of pandemic phenomena and their consequences, the effects of globalization and informatization, requiring a conceptual technological breakthrough in various areas of functional specialization, provoke the need to transform the model of sustainable economic growth of the state economic system in the near future.

In conditions of geopolitical instability, innovative activity is becoming one of the key factors in ensuring the state competitiveness in the world market. However, at present, the Russian Federation remains an inconspicuous participant in the global market for advanced production technologies. The share of finished science-intensive products (excluding nuclear technologies and the arms market) is only $0.6 \%$, which creates a high risk of lagging behind technological world leaders and low economic security in the future. [1]

\footnotetext{
*Corresponding author: lana_belikova@mail.ru
} 
In this regard, the task of intensifying innovative activity becomes very urgent, and its solution largely depends on the ability and readiness of society to actively create and use innovations as a resource for long-term socio-economic development, which is determined by the state of the innovation ecosystem. Innovations in construction are of particular importance here, as they contribute to improving the quality and reducing the cost of finished construction products, which are becoming more affordable. This requires economics to expand the methodological basis for assessing the innovation ecosystem capabilities to expanded reproduction of innovations, which ultimately allows determining new directions of state socio - economic policy. Therefore, the purpose of this study is to concretize the theoretical provisions and assess the reproductive potential of the innovation ecosystem.

The ecosystem approach in the field of innovation is given considerable attention by the modern scientific community, as it allows to consolidate knowledge from different areas, in particular, the theory of innovation, strategic management, systems theory, the theory of natural and biological areas [2-4].

For the first time, the concept of an innovation ecosystem was mentioned in the work of R. Ander, who defined the innovation ecosystem as a cooperation mechanism, with the help of which economic actors combine their individual proposals into an agreed customeroriented solution [6]. Tolstykh T.O. understands an innovation ecosystem as "a symbiosis of economic entities and their microspheres, where the complementarity of their common efforts allows them to catalyze the creation of new effective products, ideas, methods" [7]. Smorodinskaya N.V. focuses on the network nature of the innovation ecosystem in modern economic activity, emphasizing the motivation of subjects in positive transformations of the economy through innovation in the interpretation of the phenomenon under study [8]. All these definitions emphasize the special role of the innovation activity subjects, their motivation in innovation. This thesis is reflected in the methodologies for assessing the innovation ecosystem development, where the criteria for the innovations' effectiveness are formed on the basis of the performance indicators of economic entities, which does not reflect the ability of the innovation ecosystem not only to create, but also to implement the innovations $[9,10]$.

Grigorudis E., Campbell in their research come to the conclusion that an innovation ecosystem is a broader concept than a set of subjects, namely, it is a multi-level, multimodal, multi-node and multi-agent system in which subjects (actors), resources and institutions interact, in the process what flows of fundamental knowledge and capital are formed [11]. This concept is revealed in the work of O. Granstrand, M. Holgersson, who, under the concept under study, consider the evolving set of actors, their types of activities and resources, as well as the institutions and relations, including complementary and substitute relations that are important for innovation [12]. However, the authors do not disclose possible directions for analyzing the effectiveness of the innovative ecosystems' functioning from an instrumental point of view.

The representation of the innovation ecosystem as a mechanism of interaction between the knowledge environment and the business environment is of interest, which is reflected in the works of BA Akhmadeev, NA Moiseev, NA Beketov, SD Proskurin, OV Ryzhkova [5, 13-15]. For example, Ryzhkova O.V., Borodkina V.V. define an innovation ecosystem as a set of subjects and their interrelationships, acting as a catalyst for the interaction of participants for the transformation, exchange, dissemination and effective distribution of knowledge and other resources, which results in the transformation of an idea into a market product or service and its commercialization [5]. It examines the ability of an innovation ecosystem not only to generate new fundamental and applied research, but also the possibility of their subsequent implementation in society with a positive economic effect. Within the framework of this approach, the methodology for assessing the innovation 
ecosystem development is based on the analysis of the innovation result integration degree into economies of different levels [13, 16].

In our opinion, the innovation ecosystem should be considered from the standpoint of its ability to expand the reproduction of innovations, which are not only a body of knowledge registered in patents, but a kind of material product (product or service) that creates new value for society in the process of its use. In this sense, the innovation ecosystem has more opportunities than the accumulation of knowledge, although this is also important. An innovative exo-system is not only about innovation. It is based on the active movement of resources and capital flows, which must be used effectively. Therefore, attention should be paid to each stage of the innovations reproduction, in particular, the ability of innovations to improve the existing products and technologies, the possibility of their recreation and scaling using the available resource potential, the possibility of unhindered exchange, commercialization in society and capitalization of the financial result from implementation. It is in this case that innovation can act as a strategic resource for economic growth.

In the author's view, an innovation ecosystem is an institutionally organized mechanism that regulates the relations of economic entities interested in intensifying the technological development of the innovative ideas and products' reproduction, as well as a set of resource and cash flows determined in the process of this interaction.

The process of innovations' reproduction within the framework of an innovation ecosystem is rather complicated, since in many respects its success depends on a wellcoordinated mechanism of targeted actions on the part of economic entities that have a certain set of tasks, taking into account their dominance at a particular stage of the reproduction process. The main economic entities of the innovation ecosystem should include: direct participants - the state (state and municipal authorities), the scientific community (universities, research institutes, experts, etc.), the business community (large, medium, small innovative and commercial enterprises, small innovative enterprises, investment funds, investors, coworking spaces), subjects of innovation infrastructure (business incubators, accelerators, technology parks), an indirect participant - the population.

The state of the innovation ecosystem as the ability to actively create and implement innovations will be characterized by its reproductive potential, which is mediated by the characteristics of each stage of reproduction. Accordingly, the methodology for assessing reproductive potential should be based on identifying the innovation reproductive process main stages' specifics.

The development and launch of an innovative product on the market can be long-term, have a high capital intensity and be more active in promotion, which generates numerous risks of not receiving the expected economic or social effect. In this regard, we consider it expedient to present the process of the innovation ecosystem reproduction through the construction projects' implementation stages, since the investment objects in construction are capital-intensive, their implementation is associated with a certain degree of risk, which requires a careful selection of projects [17-18]. Taking into account the above-mentioned, the main stages of the innovation reproduction process within the innovation ecosystem can be presented in Table 1.

Table 1. Stages of innovation reproduction in innovation infrastructure.

\begin{tabular}{|l|l|c|c|}
\hline $\begin{array}{c}\text { Reproduction } \\
\text { stage }\end{array}$ & \multicolumn{1}{|c|}{ Tasks to be solved } & $\begin{array}{c}\text { Capital and } \\
\text { resource flows }\end{array}$ & Participants \\
\hline Production: & $\begin{array}{l}\text { The process of materialization of innovations - movement from idea to } \\
\text { finished product }\end{array}$ \\
\hline a) conceptual & Initiative to create an & Grants, own funds, & Science \\
\hline
\end{tabular}




\begin{tabular}{|c|c|c|c|}
\hline stage & $\begin{array}{lr}\text { innovative } & \text { product, } \\
\text { generation of } & \text { ideas, creation } \\
\text { of new } & \text { knowledge, } \\
\text { fundamental } & \text { research, } \\
\text { consolidation of } & \text { intellectual } \\
\text { rights } & \end{array}$ & $\begin{array}{l}\text { investments } \\
\text { customers, human } \\
\text { capital }\end{array}$ & $\begin{array}{l}\text { community } \\
\text { The state }\end{array}$ \\
\hline $\begin{array}{l}\text { b) expertise } \\
\text { and } \\
\text { justification } \\
\text { (startup) }\end{array}$ & $\begin{array}{l}\text { Discussion and examination } \\
\text { of the project, assessment of } \\
\text { the possibilities of production } \\
\text { and sale of the product, search } \\
\text { for capital, analysis of risks } \\
\text { and measures to mitigate } \\
\text { them, financial justification, } \\
\text { search for investors }\end{array}$ & $\begin{array}{l}\text { Direct investments } \\
\text { customer, venture } \\
\text { investments bank } \\
\text { loans, business } \\
\text { angel investments, } \\
\text { human capital }\end{array}$ & $\begin{array}{l}\text { Science } \\
\text { community } \\
\text { Business } \\
\text { community } \\
\text { Innovative } \\
\text { infrastructure }\end{array}$ \\
\hline $\begin{array}{l}\text { c) the stage } \\
\text { of design, } \\
\text { testing and } \\
\text { finished } \\
\text { product } \\
\text { creation } \\
\text { (start-up) }\end{array}$ & $\begin{array}{l}\text { Applied research, } \\
\text { development work and } \\
\text { technological work, } \\
\text { prototyping, finding partners, } \\
\text { normative organization of } \\
\text { relations between subjects and } \\
\text { partners, securing ownership } \\
\text { of the result of intellectual } \\
\text { work or a finished product }\end{array}$ & $\begin{array}{l}\text { Direct investments } \\
\text { customer, venture } \\
\text { investments bank } \\
\text { loans, business } \\
\text { angel investments, } \\
\text { human and } \\
\text { technological } \\
\text { capital }\end{array}$ & $\begin{array}{l}\text { Science } \\
\text { community } \\
\text { Business } \\
\text { community } \\
\text { Innovative } \\
\text { infrastructure }\end{array}$ \\
\hline Distribution & $\begin{array}{l}\text { Determination of the } \\
\text { proportion of the use of } \\
\text { resources for the creation or } \\
\text { implementation of a finished } \\
\text { innovative product between } \\
\text { participants in economic } \\
\text { relations, inter-territorial and } \\
\text { intersectoral distribution, } \\
\text { financing of innovation } \\
\text { marketing }\end{array}$ & $\begin{array}{l}\text { Own funds, } \\
\text { investments of the } \\
\text { customer }\end{array}$ & $\begin{array}{l}\text { The state - } \\
\text { Business } \\
\text { community }\end{array}$ \\
\hline Exchange & $\begin{array}{l}\text { The innovative idea transfer } \\
\text { from one economic entity to } \\
\text { another based on the } \\
\text { establishment of property } \\
\text { rights, which is supported by } \\
\text { contractual and financial } \\
\text { relations, financing of } \\
\text { innovation marketing }\end{array}$ & $\begin{array}{l}\text { Income from the } \\
\text { implementation of } \\
\text { innovations, own } \\
\text { funds, funds of } \\
\text { investors, partners }\end{array}$ & $\begin{array}{l}\text { The state - } \\
\text { Business } \\
\text { community } \\
\text { Population }\end{array}$ \\
\hline Consumption & $\begin{array}{l}\text { Use, application of an } \\
\text { innovative product by the } \\
\text { consumers (introduction of } \\
\text { innovative technology in the } \\
\text { production process, } \\
\text { management; meeting the } \\
\text { needs of the population), } \\
\text { financing the process to } \\
\text { obtain feedback }\end{array}$ & $\begin{array}{l}\text { Income from the } \\
\text { implementation of } \\
\text { innovations, own } \\
\text { funds, funds of } \\
\text { investors, partners }\end{array}$ & $\begin{array}{l}\text { The state - } \\
\text { Business } \\
\text { Population }\end{array}$ \\
\hline
\end{tabular}


The production stage is large enough and can be long-term. Here an innovative product goes through its production cycle: from the formation of an idea to the release of the final product. The tasks to be solved within the framework of the stages of exchange, distribution and consumption will depend on what is ultimately subject to implementation - an innovative idea or product, which may entail a change in the sequence of phases or their joint course. In the process of consumption, the usefulness of innovations is of an individual and social nature, which is expressed, for example, in an increase in the financial results of a business, an increase in the quality of life, and an increase in the gross domestic product [17].

Thus, the presentation of the innovation ecosystem from the standpoint of the reproduction process organization makes it possible to assess its ability not only to create, but also to introduce the innovations into the socio-economic life of society, to identify the corresponding problems and find effective ways to intensify innovation.

\section{Materials and methods}

The formed theoretical representation of the innovation ecosystem allowed the authors to determine the central provisions of the methodology for assessing the reproductive potential of the innovation ecosystem, which is based on the innovation activities quality implementation analysis by the stages of the reproductive process, which allows us to determine the area of responsibility and tasks of business entities in order to find ways to activate innovative activity and synchronize flows resources and capital at each specific stage of production and implementation of innovative products.

An innovation ecosystem is formed at the global, national, regional, corporate and individual levels. However, it is the regional innovation ecosystem that is the most important part of the national innovation ecosystem. The territory appears both as a customer and a consumer of innovative products. The production of innovations is carried out in a specific region with a characteristic resource base, institutional conditions, and the population economic activity. Local authorities are able to most clearly define the urgent problems of the regional community, which can be solved through the introduction of innovations. In this connection, the meso-environment appears not only as a geographic space for the innovation localization, but also as a diffusion socio-economic system that sublimates in itself the economic, demographic, infrastructural, institutional, and newcreative potential, which is necessary for the high-quality reproduction of innovations. Therefore, we consider it expedient to interpret the methodology for assessing the reproductive potential of the innovation ecosystem through the analysis of the regional systems. At the same time, the proposed methodology can be used to analyze the sectoral areas of the innovation ecosystem functioning, for example, the potential for the reproduction of innovations in construction.

The method for assessing the reproductive potential of the innovation ecosystem of the region is based on the use of the index method. It is based on the calculation of the integral index through a set of composite indices, each of which characterizes a specific phase of the reproductive process based on the official statistical indicators of the functioning of the region (formula 1).

$$
I_{R P I E}=a_{1} \times I_{\text {prod }}+a_{2} \times I_{\text {distrib }}+a_{3} \times I_{\text {exchange }}+a_{4} \times I_{\text {consump }}
$$

where $I_{R P I E}$ is an integral index of the reproductive potential of the region's innovation ecosystem;

$I_{\text {prod }}, I_{\text {distrib }}, I_{\text {exchange }}, I_{\text {consump }}$ are the composite indices characterizing the features of the stages of the innovation reproduction process, respectively; 
$a_{i}$ is the weight of the $\mathrm{i}$-th factor, determined expertly based on their capacity at each stage of reproduction [19].

In this case, the composite index is formed by processing the primary statistical data indicators of the development of innovative activities of the regions, published by the Federal State Statistics Service and is determined by the following formula 2:

$$
I_{i}=\sum_{j=1}^{n} j_{i} \times \frac{i_{1}}{i_{0}}
$$

where $I_{i}$ is a summary of the corresponding stage of the reproduction process;

$j_{i}-$ is the weight of the $\mathrm{j}$-th indicator (primary statistical indicator), determined by the formula $1 / \mathrm{n}$, since all used primary data have the same reliability;

where $i_{1}-$ is an actual indicator value;

where $i_{0}-$ is a "reference" indicator value;

$\mathrm{n}-$ is a number of assessment indicators.

Primary indicators are formed from the official data of the Federal State Statistics Service and represent the following reproduction process corresponding stages characteristic indicators' combination:

1. Production indicators reflect the involvement of potential participants in innovative activities and the actual volume of innovative goods created in the region.

- number of higher educational institutions, units;

- level of innovative activity of enterprises, percent;

- developed advanced production technologies, units;

- volume of innovative goods in the total mass of goods, percentage;

2. Distribution indicators characterize the endowment of the innovation ecosystem with physical resources:

— number of personnel engaged in research and development, people;

- number of researchers with a scientific degree, people;

- number of organizations engaged in the development and support of innovations, units.

3. Exchange indicators characterize cash flows:

- the volume of internal expenditures on innovations per capita, million rub. per person;

- share of internal costs for innovation in gross regional product, percentage;

- costs of innovative activities of organizations, million rubles.

4. Consumption indicators allow us to assess the effectiveness of the innovative products' introduction, which is indirectly expressed in an increase in economic development in the region:

- the efficiency of using advanced technologies, calculated as the ratio of developed advanced technologies to those actually used as a percentage;

— investments in fixed assets, million rubles;

- gross regional product, million rubles.

The region innovation ecosystem reproductive potential integral index value scale is presented in Table 2 .

Table 2. The value of the integral index of the reproductive potential of the innovation ecosystem of the region.

\begin{tabular}{|l|l|}
\hline $\begin{array}{l}\text { The region innovation ecosystem reproductive } \\
\text { potential integral index value }\end{array}$ & Reproductive potential level \\
\hline $\mathrm{I}_{\mathrm{RPIE}}>86$ & High \\
\hline $0.70<\mathrm{I}_{\mathrm{RPIE}}>0.85$ & Average \\
\hline
\end{tabular}




\begin{tabular}{|l|l|}
\hline $0.40<\mathrm{I}_{\mathrm{RPIE}}>0.69$ & Low \\
\hline $0<\mathrm{I}_{\mathrm{RPIE}}>0.40$ & Very low \\
\hline
\end{tabular}

In general, the system of indicators can be supplemented with the indicators that are relevant to the objectives of a particular study, it is possible to use the non-statistical data from special private studies.

\section{Results and Discussions}

To test the methodology for assessing the reproductive potential of the innovation ecosystem of the region, the authors selected the most innovatively active regions of the Southern Federal District: Rostov Oblast, Krasnodar Krai, Volgograd Oblast, Astrakhan Oblast, and the Republic of Crimea. The values of indicators achieved in the most successful region from the point of view of the country's innovative development were used as the reference value of the indicator. For the Russian Federation, such a region is the Republic of Tatarstan, which is one of the strongest innovators [18].

Table 3 shows the result of calculating the integral index of the reproductive potential of the innovation ecosystem for the selected regions for five years.

Table 3. Integral index of the reproductive potential of the regions of the Southern Federal District.

\begin{tabular}{|l|c|c|c|c|c|c|c|c|c|c|}
\hline Region & 2015 & Level & 2016 & Level & 2017 & Level & 2018 & Level & 2019 & Level \\
\hline $\begin{array}{l}\text { Rostov } \\
\text { Oblast }\end{array}$ & 0.73 & average & 0.79 & average & 0.75 & average & 0.73 & average & 0.70 & average \\
\hline $\begin{array}{l}\text { Krasnodar } \\
\text { Krai }\end{array}$ & 0.81 & average & 0.76 & average & 0.84 & average & 0.79 & average & 0.70 & average \\
\hline $\begin{array}{l}\text { Volgograd } \\
\text { Oblast }\end{array}$ & 0.42 & low & 0.39 & $\begin{array}{l}\text { very } \\
\text { low }\end{array}$ & 0.34 & $\begin{array}{l}\text { very } \\
\text { low }\end{array}$ & 0.32 & $\begin{array}{l}\text { very } \\
\text { low }\end{array}$ & 0.30 & $\begin{array}{l}\text { very } \\
\text { low }\end{array}$ \\
\hline $\begin{array}{l}\text { Astrakhan } \\
\text { Oblast }\end{array}$ & 0.22 & $\begin{array}{l}\text { very } \\
\text { low }\end{array}$ & 0.21 & $\begin{array}{l}\text { very } \\
\text { low }\end{array}$ & 0.17 & $\begin{array}{l}\text { very } \\
\text { low }\end{array}$ & 0.19 & $\begin{array}{l}\text { very } \\
\text { low }\end{array}$ & 0.19 & $\begin{array}{l}\text { very } \\
\text { low }\end{array}$ \\
\hline $\begin{array}{l}\text { Republic } \\
\text { of Crimea }\end{array}$ & 0.16 & $\begin{array}{l}\text { very } \\
\text { low }\end{array}$ & 0.16 & $\begin{array}{l}\text { very } \\
\text { low }\end{array}$ & 0.22 & $\begin{array}{l}\text { very } \\
\text { low }\end{array}$ & 0.19 & $\begin{array}{l}\text { very } \\
\text { low }\end{array}$ & 0.19 & $\begin{array}{l}\text { very } \\
\text { low }\end{array}$ \\
\hline
\end{tabular}

According to Table 3, the average level of reproductive potential relative to the period under study is in the Rostov Oblast and Krasnodar Krai, which does not contradict other studies in this area. In particular, in the rating of innovative development of the subjects of the Russian Federation of the Higher School of Economics, these regions are in the second echelon of innovatively active territories [20]. Volgograd, Astrakhan regions, the Republic of Crimea have a very low level of reproductive potential of the innovation ecosystem. In these regions, an intensification of policies to support and intensify innovation is required.

For a structural analysis of the reproductive potential, it is possible to study the composite indices in order to identify the most problematic stages of the reproductive process, which makes it possible to select specific tools to improve the efficiency of the region's innovation ecosystem. The calculation results are presented in Table 4.

Table 4. Composite indices characterizing the features of the stages of the innovation ecosystem reproduction process.

\begin{tabular}{|c|c|c|c|c|c|c|c|c|c|c|c|c|}
\hline \multirow[t]{2}{*}{ Region } & \multicolumn{4}{|c|}{2017} & \multicolumn{5}{|c|}{2018} & \multicolumn{3}{|c|}{2019} \\
\hline & $\mathrm{I}_{\text {prod }}$ & $\mathrm{I}_{\text {distrib }}$ & $\mathrm{I}_{\text {exchange }}$ & $\mathrm{I}_{\text {consump }}$ & $\mathrm{I}_{\text {prod }}$ & $\mathrm{I}_{\text {distrib }}$ & $\mathrm{I}_{\text {exchange }}$ & $\mathrm{I}_{\text {consump }}$ & $\mathrm{I}_{\text {prod }}$ & $I_{\text {distrib }}$ & $\mathrm{I}_{\text {exchange }}$ & $\mathrm{I}_{\text {consump }}$ \\
\hline $\begin{array}{l}\text { Rostov } \\
\text { Oblast }\end{array}$ & 0.41 & 0.83 & 0.47 & 0.96 & 0.46 & 0.78 & 0.37 & 0.94 & 0.60 & 0.82 & 0.51 & 0.9 \\
\hline $\begin{array}{l}\text { Krasno } \\
\text { dar } \\
\text { Krai }\end{array}$ & 0.69 & 0.85 & 0.30 & 0.95 & 0.65 & 0.81 & 0.14 & 0.96 & 0.52 & 0.72 & 0.19 & 0.9 \\
\hline Volgo- & 0.32 & 0.31 & 0.18 & 0.56 & 0.27 & 0.30 & 0.17 & 0.56 & 0.21 & 0.30 & 0.19 & 0.55 \\
\hline
\end{tabular}




\begin{tabular}{|c|c|c|c|c|c|c|c|c|c|c|c|c|}
\hline $\begin{array}{l}\text { grad } \\
\text { Oblast }\end{array}$ & & & & & & & & & & & & \\
\hline $\begin{array}{l}\text { Astrak- } \\
\text { han } \\
\text { Oblast }\end{array}$ & 0.19 & 0.12 & 0.06 & 0.30 & 0.23 & 0.12 & 0.05 & 0.32 & 0.18 & 0.13 & 0.08 & 0.34 \\
\hline $\begin{array}{l}\text { Repub- } \\
\text { lic of } \\
\text { Crimea }\end{array}$ & 0.13 & 0.19 & 0.31 & 0.30 & 0.13 & 0.18 & 0.13 & 0.36 & 0.10 & 0.19 & 0.18 & 0.31 \\
\hline
\end{tabular}

Regions with an average value of the innovation ecosystem reproductive potential (Rostov Oblast and Krasnodar Krai) need to stimulate the stages of production and exchange. The innovation policy of territories with very low reproductive potential can be based on stimulating the production phase, distribution and exchange of innovations.

\section{Conclusion}

An innovation ecosystem is an institutionally organized mechanism that regulates the relations of those interested in intensifying the technological development of business entities regarding the reproduction of innovative ideas and products, as well as the resource and cash flows determined in the process of this interaction. Therefore, it is advisable to assess the innovation ecosystem from the standpoint of its potential for the reproduction of innovations.

The innovations reproduction stages within the innovation ecosystem should be considered both in relation to the movement of innovative ideas and ready-made products. The stages can be integrated, change the sequence. The production stage is the most capacious, which is associated with a careful selection of innovative ideas, the specifics of the creation and resource provision of innovations.

The methodology for assessing the reproductive potential of an innovation ecosystem consists in calculating the integral index for a group of summary indicators reflecting the specifics of the reproductive process each stage course. The methodology was tested at the regional level, taking into account the available official statistical information. However, the assessment is possible in the sectoral context, using the statistical data obtained from specialized studies [21].

The results of assessing the reproductive potential of an innovation ecosystem can be used to search for additional tools for the innovative activities development at each stage of the reproductive process, as well as in the formation of regional and national strategies for innovative development.

\section{References}

1. $\mathrm{RBC}$

https://www.rbc.ru/technology_and_media/13/04/2021/607478fc9a794731d03611ab (2021)

2. D.J. Jackson, National Science Foundation, (2018)

3. M. G. Russell et al., Triple Helix IX International Conference, (2011)

4. M.V. Ledeneva, T.A. Plaksunova, Vestnik VSUIT 80, 4 (2018)

5. O.V. Ryzhkova, V.V. Borodkina, Industrial Policy in the Digital Economy 302-310 (2017)

6. R. Adner, Match, Harvard business review 84(4), 98 (2006)

7. T. O. Tolstykh, A. M. Agaeva, Science today: challenges and solutions 73 (2020)

8. N. V. Smorodinskaya Innovations 7, 189 (2014) 
9. S.S. Zmiyak, E.A. Ugnich, P.M. Taranov, Scientific Bulletin: finance, banks, investments 1, 163-170 (2019)

10. G. I. Popodko, S. N. Nagaeva, Issues of Innovative Economy 9, 1, 90 (2019)

11. E.G. Carayannis, D.F.J. Campbell, International Journal of Technology Management 46, 3/4. 201-234 (2009)

12. O. Granstrand, M. Holgersson, Technovation, 90-91 (2020)

13. B.A. Akhmadeev, N.A. Moiseev, Bulletin of the Russian University of Economics named after G.V. Plekhanov 4, (2016)

14. G. Ya.Belyakova, S. D. Proskurnin, European Social Science Journal 9, 8-29 (2017)

15. H.V. Beketov, Problems of the modern economy 4 (2004)

16. O.V. Ryzhkova, V.V. Borodkina SPbSPU Scientific and Technical Bulletin 11, 1, 146-153 (2018)

17. R. R. Tugusheva Models, systems, networks in economics, technology, nature and society 1, 47-48 (2017)

18. O.S. Prosyanik, R. G. Abakumov Innovative economy 2, (2014)

19. S. V. Belikova, Proceedings of higher educational institutions. North Caucasus region, 6 (2013)

20. Rating of innovative development of the constituent entities of the Russian Federation https://www.hse.ru/primarydata/rir (2021)

21. O. E. Ivanova, A. A. Krivorotova, Scientific research of higher education in priority areas of science and technology, 33-36 (2018) 